\title{
From Sochi - 2014 to FIFA - 2018: a fading sovereignty?
}

\section{Andrey Makarychev \& Alexandra Yatsyk}

To cite this article: Andrey Makarychev \& Alexandra Yatsyk (2017) From Sochi 2014 to FIFA - 2018: a fading sovereignty?, Sport in Society, 20:4, 476-488, DOI: 10.1080/17430437.2015.1100886

To link to this article: https://doi.org/10.1080/17430437.2015.1100886

\section{曲 Published online: 03 Nov 2015.}

Submit your article to this journal $\pi$

Цlll Article views: 302

Q View related articles $₫$

View Crossmark data 


\title{
From Sochi - 2014 to FIFA - 2018: a fading sovereignty?
}

\author{
Andrey Makarychev ${ }^{\mathrm{a}}$ and Alexandra Yatsyk ${ }^{\mathrm{b}}$ \\ anstitute of Government and Politics, University of Tartu, Tartu, Estonia; ${ }^{b}$ Center for Cultural Studies \\ of Post-Socialism, Kazan Federal University, Kazan, Russia
}

\begin{abstract}
In this article, we uncover the dynamics and the evolution of Russian discourses of sovereignty before and after the Sochi 2014 Olympic Games using some elements of Foucauldian methodology and constructivist reading of sovereignty as an institution. We argue that there is a discrepancy between the rhetoric of sovereign power and the institutional practices in which it is embedded. It leads us to theorize that sovereignty discourses are contextual, unstable and constitutively shaped by commitments taken as key elements of international socialization. In the case of Russia, these discourses can be divided into three groups: pre-Sochi, post-Sochi and pre-World 2018 Cup discursive formations. As we venture to demonstrate, Putin's model of sovereignty is in crisis, yet it has support, both domestic and international. In the near future, sport is likely to remain one of those spheres of high visibility where the ideology of surviving under sanctions and counter-attacking the West will be reified.
\end{abstract}

\section{Introduction}

This paper, based on our previous research on different discursive frames in which the Sochi Olympics could be deployed (Makarychev and Yatsyk 2014), seeks to trace the dynamics and the evolution of Russian discourses of sovereignty before and after the 2014 Games. Comparing pre-Olympic and post-Olympic discourses, we project them to the forthcoming sports mega events in Russia, with the FIFA World Cup in 2018 at its core. In terms of the number of co-host cities, the scope of the FIFA Cup is even larger than the winter Olympic Games held in Sochi in February 2014. Yet the Olympic Games in Sochi and the World Football Cup seriously differ from each other in many important respects.

The core of the difference lies in the drastic changes in the structure of Russia's sovereignty, the pivotal concept justifying and legitimizing Putin's regime. The sports milieu is susceptible to political articulations, and is widely used by sovereign powers. By sovereignty one may understand 'the exclusive right to excercise, within a specifiable territory, the functions of a government and be answerable to no higher authority' (Parker and Adler-Nissen $2012,787)$. The Sochi Olympics were held at the heyday of sovereign power articulated through concepts of normalization, security and the retrieval of Russia's role as a great 
power. The annexation of Crimea that Putin started orchestrating even before the closure of the Sochi Games, was presented in the official Kremlin's discourse as a gesture of strong sovereign power protecting its compatriots and thus practically implementing the Russian world concept.

Yet it was exactly this act of sovereignty manifested through the acquisition of a new territory that became the driving force for a chain of processes ultimately conducive to the severe crisis of Kremlin's model of sovereign power. As an effect of its Ukraine policy, Moscow is subject to international economic and financial sanctions, as well as political isolation. Many components of this crisis directly affect the preparation for the FIFA 2018 World Cup.

In this article, we intend to uncover the logics of these changes using some elements of Foucauldian methodology of genealogical research of discourses on sovereignty. In this tradition of research sovereignty appears as 'a metaphysical notion which totalizes power around the constitution of an autonomous, self-identical subject' (Singer and Weir 2006, 451). Foucault looked for 'variations in the meaning and use of the notion of sovereignty' (Selby 2007, 329) that is key for understanding how political subjects are constituted by different configurations of discourses and in 'heterogeneous discursive zones' (Widder 2004, 416). The Foucauldian genealogical method presupposes an emphasis on identifying the sources of 'immanent discontinuities' (Rosenow 2009, 509) in sovereign discourses that unveil, under close scrutiny, a variety of different tactics, strategies and rationalizations of power. Along these lines, one may claim that 'sovereignty functions not as a fixed legal principle, but as a flexible discourse ... that establishes a set of rules that enable some constructions of sovereignty as accurate and useful while disabling others as irrelevant and harmful' (Kuus 2002, 407).

This theorizing is consistent with constructivist reading of sovereignty as an institution that exists only in virtue of certain intersubjective understandings and expectations ... The sovereign state is an ongoing accomplishment of practice, not a once-and-for-all creation of norms that somehow exist apart from practice' (Wendt 1992, 413). The application of Wendt's argument to Russia's policies on mega sports events produces a controversy to be explored in this article. On the one hand, global sports is a social milieu generative of sovereignty-centric discourses that are articulated through interrelated concepts of exceptionality, nationalism and security. Yet on the other hand, as many experts deem, global sports organizations often tend to choose hosts for world-scale events among countries 'that are considered institutionally weak and corrupt ... As easy-going partners in aggressive negotiations, they are prone to yield to the considerable influence of the quasi-corporate international sports federations' (Wloch 2012, 307). This discrepancy between the rhetoric of sovereign power and the institutional practices it is embedded in makes us theorize sovereignty discourses are contextual, unstable and constitutively shaped by commitments taken as key elements of international socialization. In the case of Russia, these discourses can be divided into three groups to be discussed below in detail: pre-Sochi, post-Sochi and pre-World Cup discursive formations.

\section{Kremlin's pre-Sochi narrative: glorification, celebration, consolidation}

The Sochi-centric discourse contained a variety of different layers of meanings and imageries representing Russia, its identity and power ambitions (Saprykin 2015). In the context of the 
Sochi debate, many foreign experts addressed their expectations directly to the Kremlin as the main subject of power that 'should start with getting serious about fighting corruption, rebuilding the rule of law, promoting democracy, clamping down on extremism and creating a better business environment. The release of Mikhail Khodorkovsky, the Pussy Riot punk rock band and the Greenpeace activists from jail was a good start', claims Cohen (2014).

Yet in staging the Sochi Olympics, the Kremlin on behalf of the Russian collective self was eager to send its own messages to the world. Of quintessential importance was the opening ceremony that both culturally and politically legitimized Russia's imperial identity in general and the Soviet period in particular. It is this message that can be, in particular, helpful for comprehending the logic behind Russia's militant policy towards Ukraine and the consolidation of the Putin-centric discourse cemented on the basis of three components to be analysed further - nationalism, exceptionality and security.

\section{Nationalism}

Politicization of sports as one of the components of power relations comes from many sources. Its core has to be searched in a conflict between nationalism and globalization, inherent for all sportive mega events (Nili 2009). The 'structural importance of the nation persists despite the increasing circulation of sportspeople around the globe as part of the new international division of cultural labour' (Rowe 2003, 286). For many countries sports became an important driver for moulding national identities 'that both internally unite people and draw external boundaries against others' (Cho 2009; van Hilvoorde, Elling, and Stokvis 2010).

The Sochi Olympics confirmed that sovereignty connotes articulation of national identities and patriotism. Vitaly Mutko, Russian Sports Minister, claimed that Russia's key competitive advantage that makes it different from the UK or Brazil is the clear support from the national leaders, along with enthusiasm in the host cities (Gazeta.ru 2013). For boosting the feelings of nationalism, the symbolic dimension is of primordial importance, as epitomized by the idea of Russia 'raising from the knees' and returning to the group of great powers. Celebration of the Games turned into a glorification of Russia and anticipation of a politically motivated performance, auguring the heyday of Russia's power, as evidenced, for example, by the lyrics of the unofficial anthem of the Sochi Olympics. It ascertains that 'Russia deserved' the Games that are a matter of national pride, and for the sake of success the country needs to stay united, pushing all disputes aside (YouTube 2015).

\section{Exceptionality}

Speaking about the 'self-justifying and self-augmenting function of sovereign power' (Butler 2004, 68), Judith Butler argues that 'sovereignty extends its own power precisely through the tactical and permanent deferral of the law itself, (hence. - A.M., A.Y.) the exercise of sovereign power is bound with the extra-legal status of ... official acts' (Butler 2004, 80 ). In other words, 'sovereignty consists now in the variable application, contortion, and suspension of the law ... (It. - A.M., A.Y.) denotes a form of power that is fundamentally lawless, and whose lawlessness can be found in the way in which law itself is fabricated or suspended at the will of a designated subject' (Butler 2004, 82). 
This overlaps with Giogrio Agamben's claim that the paradox of sovereignty is manifested through the fact the sovereign is, at the same time, outside and inside the juridical order he embodies (Agamben 1998). Sovereign power consists in the impossibility of distinguishing between an outside and an outside, norm and exception ... Sovereignty, in other words, marks the limit of the juridical order - and it is this very structure ... that Carl Schmitt describes as that of the exception ... If the sovereign is, in fact, the one to whom the juridical order grants the power of proclaiming the state of exception - and, thus, the power of suspending the order's very validity - then we should properly conceive of the sovereign as standing outside the juridical order, while nevertheless belonging to it' (Minca 2007, 85).

Sports mega events give many examples of the validity of this interpretation. It is well recorded that in the lead-up to the Olympics, the Russian government introduced multiple exceptions to existing legislation, both as a response to requirements of the International Olympic Committee (IOC) and as a means of facilitating the logistics of the event (Müller 2014). For example, according to the Russian legislation, the state cannot credit financially unsustainable projects, yet the government extended tax benefits for investors in Sochi till 31 December 2015 (Zholobova 2013).

The practice of legalized exceptions was extended to the FIFA Cup. According to the Federal law 'On the Preparation and Organizing of the 2018 FIFA World Cup and 2017 FIFA Confederations Cup in the Russian Federation and the Amendment of Certain Russian Federal Legislative Acts' (108-FZ), employers were empowered to determine conditions and rules for the night work (Part 2, Article 11) without guarantees provided by the Article 154 of the federal Labour Code, which requires paying for night work at a higher rate. Article 152 of the Labour Code, which sets minimum rates for overtime payment, is not applied for World Cup 2018 employees. These provisions of the Federal Law contravene international obligations of the Russian Federation, in particular those related to the European Social Charter (Andreyev, Bol'sheva, and Gerasimova 2015).

As the practice shows, the norms that were introduced as exceptional measures for mega events can be routinized. A perfect example is the legislation that facilitates the procedure of witholding citizens' private property, to a large extent based on the Sochi experience (Shlepchenko 2013).

Sovereignty, therefore, presupposes exceptionality and discontinuation of the 'normal' legal order. This practice, being legitimized to a large extent by the Sochi Olympics, immediately afterwards was extended to other cases, including exceptionalizing the annexed Crimea as a 'special region' requiring not only extraordinary federal investments but also special legal clauses.

\section{Security}

In Slavoj Zizek's words, 'policing in the broad sense is maintaining social order and the smooth running of the social machine' (Zizek 2006). The Sochi experience makes clear that mega events are used by security services to get additional powers and install a topdown, force-based model of public order (KavkazUzel 2014). Yet Russian police's record of securing mass-scale sports events is very debatable and vulnerable to criticism. There were multiple incidents where the police disproportionally applied physical force against football players (in Nizhny Novgorod) or enforced strip search on female football fans (in 
Kazan (Super_ska_ya 2014)). The World Athletic champoinship held in Moscow in 2014 was known for multiple complains against ubiqiotous security measures from journalists and viewers (SkiRun 2013).

There is another facet of what might be dubbed securitization of sports. It was in the context of the Universiade (the World Student Games) held in Kazan in summer 2013 that Putin ordered the return of the Soviet-style GTO (an acronym that stands for 'Reday to Labour and Defense') norms of physical fitness. The case of GTO is a good example of a fusion of the collective body of the nation and the body of the sovereign ruler. According to the widely spread interpretation, the major motivation behind the reintroduction of GTO norms was to raise the stamina and vigour of conscripts (Dozhd' 2013). This biopolitization of security, with the techniques of disciplining and managing human bodies at its core (Makarychev and Medvedev 2015), after mega events in Sochi and Kazan stretched far beyond the realm of sports and became a pervasive instrument of societal control and surveillance widely practiced by the Kremlin. In the meantime, the GTO norms became an important reference point for sustaining Putin's personal image as a physically strong and healthy leader: according to his press secretary, the President's athletic qualities 'surpass all formal norms' (Gazeta.ru 2015c), which is a momentous element of Putin's political mythology.

\section{A post-Sochi afterword}

With all transmutations of sovereignty in mind, one may wonder to what extent mega events might foster changes within non-democratic regimes. The examples of the Berlin Olympics of 1936 and the Moscow Olympics of 1980 demonstrate that totalitarian regimes might use mega events not for socializing into international milieu but rather for legitimizing their international positions and using the newly acquired symbolic capital for justifying hard force-based types of policy.

The glorious narrative that emerged in the lead-up to the Sochi Olympics was consolidated by the expectation of Russia's symbolic return to a group of great powers with its might and grandeur. Yet unfortunately, mega events, instead of bringing Russia closer to the West, had an opposite effect - the Olympics provoked intensive discourse on politically boycotting the event as a gesture of protestation against homophobia in Russia. During the Sochi Olympics, Russia was widely portrayed as a country oscillating 'between fear of terror and homophobia' (Beckmann 2014). Later on, Dutch skaters threatened to boycott the world championship in Cheliabinsk in January 2015 as a protest against Russian policy in Ukraine that led, in their view, to the Malaysian Airlines jet crash in the skies over Ukraine (Zaiviay 2014). Ultimately, the founder of the soft power concept Joseph Nye ascertained that Putin 'failed to capitalize on the soft-power boost afforded to Russia by hosting the 2014 Winter Olympic Games in Sochi' (Nye 2014).

This critical legacy of Sochi is illustrative of the Putinite sovereignty as conducive to Russia's detachment from the West. What is more, the events after the Olympics put the very concept of sovereignty under trial.

\section{After Sochi: the pitfalls of sovereignty}

The post-Sochi discourses emerged under the impact of the annexation of Crimea, an event that could be interpreted as qualitative re-accentuation and radicalization of the 
sovereign power that transposed the performative and media-based symbolic domination to the sphere of military confrontation. What for the Kremlin constituted just another step ahead in asserting Russia as a great power along the lines of the opening ceremony script, was largely perceived in the West as a dramatic departure from the key message embedded in the Sochi narrative that was largely understood in the West from a different angle - namely, as representing Russia as a European nation that prioritizes cultural - as opposed to military - arguments in communicating with the world. This myth ${ }^{1}$ of an open, hospitable and tolerant Russia was destroyed by the newly adopted ideologueme of forcefully reassembling the so called 'Russian lands' and the ensuing security conflict with the EU and NATO. The Kremlin has popularized and symbolized new heros - 'polite men' in green military uniform with guns who embodied a different Russia, a country that doesn't hide its territorial ambitions and belief in its own 'special way' (Pertsev 2015). Those who predicted that the Sochi Olympics will be followed by an authoritarian devolution of the regime (Muzhdabaev 2014) have proven to be right.

The annexation of Crimea - a political act orchestrated and masterminded by Putin - was a major event that challenged the sovereignty he embodies. The post-Sochi discourse has emerged out of militarization and securitization of the symbolic capital gained, in particular, due to the Olympics, and was meant to justify Russia's policy in Ukraine, including the annexation of Crimea in the immediate aftermath of the Games.

On the one hand, after Sochi, the sovereign discourse has solidified itself on the basis of the most radical interpretation of the three nodal points mentioned above: nationalism was elevated to the point of disdain to the West, exceptionalism was routinized and, paradoxically, normalized as a power tool in critical times (economic sanctions and counter-sanctions, securitization of relations with the EU and NATO, etc.), and security itself was totalized in the name of preserving public order, which is tantamount to denying rights for public dissent in the form of rallies, meetings or demonstrations. Yet on the other hand, the hegemonic discourse was shaped by defensive notes, since it faced the necessity to justify the rationale of the Sochi project with its exorbitant budget. What resulted was a situation of the Foucauldian discursive dispersion: the hegemonic narrative fragmented into 'islands' with different messages and agendas, including the mega event fatigue in the corporate business community.

After the Olympics, the official discourse continued to defend the Sochi project and claim that it was beneficial for the city and the country in general. Acting within the logic of sovereign power, Putin claimed that 'we intentionally invested in tourist infrastructure to make our citizens leave their vacation money here instead of going abroad' (Bektimirov 2014). However, the overall tone of the debate became more sceptical. All three facets of sovereign power - exceptionality, incitement of nationalism and enhancement of a policetype of security - have gradually become vulnerable and susceptible to critique.

A major point of contestation was the questioning of the importance of the Sochi Olympics for the real needs of the country, as opposed to virtual PR projects promoted by the elite. Critics largely perceived the entire Sochi project as an illusory spectacle, a nice fairy tale to be distingiushed from 'the real life'.

It's hard to believe that it was real, - a Russian commentator confessed a year after Sochi. - The Olympiad was the last attempt to break out of the gray and gloomy reality, yet this endeavor remained a game, thus elucidating the emptiness of the Russian identity' (Davydov 2015). The post-Sochi discourse once again raised the issue of performative exceptionality of the 
Games and the mundane reality on the ground:'The billions invested in image turned into a mere concession to the IOC, because soon the world has seen a different face of Russia. And

it keeps watching. Yet which of these two faces is ours, and who are we?' (Dzichkovskiy 2015)

Many critical voices were heard from the business community: a few months prior to the Olympics German Greff, the head of 'Sberbank', has announced that his company, a key investor in Sochi, will withdraw from the project as soon as possible, since these investments play no key role in the bank's strategy (Greff 2015). Only 100 days before the Olympics main investors issued a de facto ultimatum to the government demanding tax benefits under the threat of declaring bankruptcy (Kozhanova 2013). It turned out that a year after the Sochi Olympics several hundred workers are still struggling with their former employers for retrieving their overdue salaries (News.ru 2015).

Ironically, this is also the case of the ice hockey club 'Sochi' created from scratch in 2014 with the only purpose of making some use of the Olympic stadium. The project however was far from sustainable - only a year after the team was established its representatives have made public their complaints about month-long arrear payments and pledged to use legal means for securing their salaries. 'We are fed up with constant promises... No one says anything specific. We don't know what is going on. It seems that the club is short of money, and no one needs it' (RSport 2015), the 'Sochi' capitan Nikita Schitov said.

Financially, the experience of the Sochi Olympics put Russia in the category of such former host countries as Greece that neglected open professional expertise and evaded transparent tenders. As economists claim, the most effective way of reducing costs for hosting mega events is to open them to competitive procedures (RSport 2015), which is far away from Russian practices of corruptive distribution of resources. The post-Sochi discourse opened some of the mechanisms that have led to enormous costs of the Games. According to Dmitry Bush, the chief architect of the 'Fisht' Stadium in Sochi, the Russian legislation allows to conclude contracts based on estimated project costs, which might not necessarily be rigidly substantiated. This is exactly what happened in Sochi where most of contractors, in his words, were recruited from security services: they were trusted by toplevel authorities but were short of knowledge and expertise in building and architecture. A major Russian private investor in the Sochi infrastructure, Vladimir Potanin, said that the state was constantly insisting on adding new elements to the contruction projects he sponsored - new tracks, gates, etc., which led to the everlasting rise of the total expenditures (Forbes 2014). Another reason was that for the sake of convenience the First Channel insisted on constructing a new roof for the main stadium, which raised the budget twofold (Makarov 2015). These post-factum evidences suggest that economic rationality was not at the centre of the Sochi project, and many Russian corporations were administratively forced to invest in the Olympics (Makarov and Sagomonian 2015).

\section{Anticipating 2018: 'better football than war'}

The third type of discourse, again anticipatory, is focused on the FIFA 2018 World Cup, yet - unlike the pre-Sochi discourse - it develops in drastically different conditions of declining economy and unstable national currency, which makes it much less celebratory and unified. ${ }^{2}$ Within the framework of this discourse the Sochi experience is problematized from the viewpoint of its financial repercussions (the costs of maintaining the infrastructure, etc.), and the forthcoming World Cup project is largely treated as a liability and a burden, rather 
than an asset or a source of national inspiration. This is particularly so taking into account Russia's struggle to avoid the most negative effects of isolation from the West resulted from the annexation of Crimea and support for military separatists in eastern Ukraine.

\section{Political pitfalls: Crimea and beyond}

In fact, never before has a FIFA championship been hosted by a country under painful economic sanctions and in a state of de facto military conflict with its neighbour. The preparation for the FIFA 2018 Cup proceeds under economic sanctions against Russia and a new wave of boycotting petitions (SecureAvaaz 2015). The political reality is that Russia is facing isolation 'which, in the narrow footballing context, is bound to cast doubt on the viability of a World Cup that will serve president Vladimir Putin and his oligarchical cronies ... Already we are in the highly anomalous position of sending a World Cup to a country that is helping to destroy a European Championship host. Thus the 2018 World Cup is effectively at war with Euro 2012' (Hayward 2015) co-hosted by Ukraine.

The question of the inclusion of Crimean clubs in the Russian championship was a major political challenge that the Russian Football Union (RFU) faced after the annexation of this Ukrainian peninsula. The records of an RFU session held in August 2014 and leaked to the press elucidated important facets of sovereign power in the specific context of the FIFA World Cup. The dilemma that the RFU faced - to decide on whether Crimean clubs ought to be integrated into the Russian league - has clearly demonstrated that this organization is capable of operating only as an appendage of the sovereign power. Its members recognized that their contribution to winning the bid for the FIFA World Cup was 'not more than 2-3\%, while you know who did most of the job' (Sukhotin 2014). Having rightly realized that the RFU needs to take a political (either - or) decision, they got stuck and ultimately adjourned the voting to clarify the Kremlin's position: 'if we are tasked with getting adjusted (to the Kremlin-approved policy - A.M., A.Y.), we'll certainly do so. Anyway we'll choose the motherland over all the rest. If there is a direct instruction (to vote for including Crimean clubs - A.M., A.Y.) - then it's Ok' Thus, the whole debate revolved around the question of 'whether the first man in the state needs this' (Sukhotin 2014).

As the sovereign, 'Putin put everything at stake' in his direct confrontation with Ukraine and the West, and is the 'master signifier' and the ultimate source of authority: 'The President is alone standing in the breastwork, and you dare to mull over new sanctions ... Either you flee out of the country, or behave correspondingly'. By the same token, in this illuminating discussion, Putin features as an enigmatic figure with uncertain preferences: 'Ok, let's image that I could give him a call and ask: Vladimir Vladimirovich, we've got a situation here. He would say - Get out of here. And he would be right'. Yet in the case of taking 'incorrect decision' Putin, as one top-level participant presumed, might go 'looking for all of us sitting here. The fears of being blacklisted by the West and 'losing what we have been doing for 25 years' were serious: 'Who will reimburse me or others 10 billion Euro of damage?', one of the sponsors of Russian football industry asked. The evident politicization of this issue in fact immobilized the RFU and led one of its members to assume that given the complexity of political situation, 'the World Cup 2018 might not necessarily be the key card to play with' (Sukhotin 2014). 
Ultimately (and ironically), the 2018 Football Cup became a constraining factor for the Putinite sovereign power, since international sports institutions (UEFA in particular) were the only authorities that de facto - and indirectly, under the threat of sanctions - forced the Kremlin to implicitly recognize the limitations of its ability to fully incorporate Crimea: the RFU had to ultimately revoke its decision on including Crimean football clubs into the Russian league (Golovin 2015). This inclusion - exclusion 'game' reveals vulnerabilities and inconsistencies within the structure of sovereign power that for the sake of hosting the mega event has to compromise on something that constitutes the core of Putin's ideology - the reincorporation of Crimea into Russia as a gesture of restoring 'historical fairness' and a boost to the 'Russian world' concept.

\section{Financial pitfalls of sovereignty}

Apart from political reverberations, Russia faces huge economic troubles. Due to the shortage of resources, Russia had to ask FIFA to reduce the occupancy of two stadiums - in Kaliningrad and Yekaterinburg - from 45 to 35 thousand (RussianGovernment 2015). Russian Sports Minister Vitaly Mutko announced a 10-per cent cut in the budget for the FIFA World Cup (Gazeta.ru 2015a), and encouraged local officials to seek financial support from private donors (Klimentyev 2014). Due to financial problems caused by international sanctions the Russian government had to authorize the substitution of imported construction materials with their Russian analogues, which evoked serious doubts among experts (Sakharova 2015).

Of course, many symptoms of the crisis were visible years before. Sports mega events strengthen the practices of top-down mobilization - from enforced street cleaning by state employees to administrative pressure over corporate business (Chizhova 2014). Many experts and journalists claim that these events are economically ineffective and even detrimental (Nikolaev 2014).

The financial difficulties facing Russian football were exemplified by the 'Anzhi' club sponsored by the olygarch Suleiman Karimov who wanted to turn it into one of the richest top-level clubs, but in 2013 announced that he could no longer invest in football (Krasil'nikov 2013). In 2013 another tycoon, Roman Abramovich, the owner of the British 'Chelsea, announced that he stops financing Russian football. Other businessmen are reluctant to voluntarily invest in the FIFA World Cup project: for example, the head of 'Magafon', a major Russian cell phone operator and a partner of the Sochi Olympics, in April 2015 announced that his company has no intentions to sponsor the 2018 event (Dozhd 2015b). Yet the most serious financial crisis erupted within the RFU that for months failed to pay contract salary to the national team coach Fabio Capello, and it was only through two loans provided by the tycoon Alisher Usmanov that stabilized the situation (Gazeta.ru. 2015b), thus demonstrating both submissiveness to the government and the critical dependence of the latter on corporate business.

\section{Conclusion}

Sport mega events constitute a peculiar tier in the long story of Russia's international socialization, with its ebbs and flows, and multiple controversies. On the one hand, FIFA itself de facto encourages sovereign authoritarianism - thus, its Secretary General Gerome Valcke 
has overtly claimed that a lack of democracy is by no means a hindrance when organizing major tournaments and championships (Reuters 2013). FIFA optimistically believes that hosting the World Cup with the global attention it attracts can be a powerful catalyst for constructive dialogue between people and governments, helping to bring positive social developments and, taking into account the current level of tensions between Russia and the West, to contribute to de-escalation of the conflict (Mlssoccer 2014). Major corporate sponsors of mega events - such as Adidas - pledged to keep working in Russia, despite intense criticism of the Russian government and the corruption scandal in FIFA (Zayvyi 2015). These expectations are supported by Russian appeals to use this opportunity for easing the negative consequences of Russia's Ukraine policy and restoring confidence in Russia in the West (Gazeta.ru 2014), but without any serious changes in Russia's policies.

Yet on the other hand, Russia's sovereignty is significantly restricted by its de facto submission to the regulations of international sports organizations. As we have mentioned, it is due to UEFA's policy that a few football clubs of Crimea have to play among themselves, instead of being integrated into the Russian League. And it is due to FIFA's global anti-racist policy that RFU - though reluctantly - admited the existence of the problem in Russia and introduced the position of inspector on the issue of racism.

It is within this controversial framework that the concept of sovereignty has to be placed. As we ventured to demonstate in this article, Putin's model of sovereignty is in crisis, yet it does have resources of support, both domestic and international. In the near future sports is likely to remain one of those spheres of high visibility where the ideology of surviving under sanctions and counter-attacking the West will be reified.

\section{Notes}

1. We use the concept of myth as a semiotic construct aimed at reshaping identities, legitimizing power structures and naturalizing (de-politicizing) the existing state of affairs. See (Persson 2014).

2. This phrase comes from an interview with the mayor Evgenii Roizman of Yekaterinburg, one of the co-host cities of the FIFA-2018 Cup See: (Dozhd' 2015a).

\section{Disclosure statement}

No potential conflict of interest was reported by the authors.

\section{References}

Agamben, G. 1998. Homo Sacer: Sovereign Power and Bare Life. Stanford: Stanford University Press. Andreyev, V., A. Bol'sheva, and E. Gerasimova. 2015. "EURO 2012 and World Cup 2018: Threats to Labour Rights and Trade Union Strategies." Building and Wood Worker's International Portal. http://www.bwint.org/pdfs/Euro2012andWorldCup2018ThreatstoLabourRightsandTradeUnion StrategiesENG-Final.pdf.

Beckmann. 2014. "Olympia in Sotschi - Putins Spiele Zwischen Terrorgefahr Und Homophobie." Das Erste TV, January 17. http://www.daserste.de/unterhaltung/talk/beckmann/videos/olympiain-sotschi-putins-spiele-zwischen-terrorgefahr-und-homophobie-100.html.

Bektimirov, F. 2014. "Posle Olimpiady tam vsio razvalitsya." Gazeta.ru, January 17. http://www.gazeta. ru/sport/2014/01/14/a_5849353.shtml.

Butler, J. 2004. Precarious Life. The Powers of Mourning and Violence. London: Verso. 
Chizhova, L. 2014. 'Prazdnik sporta kak pir vo vremya chumy." Radio Free Europe, January 17. http:// www.svoboda.org/content/article/25232206.html.

Cho, Y. 2009. "Unfolding Sporting Nationalism in South Korean Media Representations of the 1968, 1984 and 2000 Olympics." Media, Culture \& Society 31 (3): 347-364.

Cohen, A. 2014. "Russia's Reputation at Risk in Sochi." The National Interest, January 23. http:// nationalinterest.org/commentary/russias-reputation-risk-sochi-9757?page=2.

Davydov, I. 2015. "Pamyati sochinskoi olympiady" Slon, January 27. http://snob.ru/selected/ entry/87000.

Dozhd'. 2013. "Vyshe, bystee, silnee.” Dozhd' TV, September 26. http://tvrain.ru/articles/vyshe_ bystree_silnee_organizator_universiady_2013_v_kazani_po_zadaniju_vladimira_putina_ vosstanavlivaet_normy_gto-353067.

Dozhd. 2015a. "'Luchshe futbol, chem voina'. Roizman, Cherdantsev i Komandnaya o tom, nuzhen li Rossii ChM-2018.” Dozhd' TV, February 25. http://tvrain.ru/articles/luchshe_futbol_chem_vojna_ rojzman_cherdantsev_i_komandnaja_o_tom_nuzhen_li_rossii_chm_2018-382841/.

Dozhd. 2015b. "Megafon ne planiruet stanovitsya sponsorom CHM-2018 v Rossii." Dozhd' TV, April 11. http://www.gazeta.ru/sport/news/2015/04/11/n_7099085.shtml.

Dzichkovskiy, E. 2015. “Igry kak predchuvstvie.” Gazeta.ru, February 7. http://www.gazeta.ru/column/ sport/dzichkovskij/6403093.shtml.

Forbes. 2014. "Milliarder na Olimpe: kak Potanin stal glavnym chastnym investorom v Sochi-214." Forbes, January 30. http://www.forbes.ru/milliardery/250267-milliarder-na-olimpe-kak-vladimirpotanin-stal-glavnym-chastnym-investorom-sochi?page $=0 \% 2 \mathrm{C} 1$.

Gazeta.ru. 2013. "Rossiya poluchila mundial chestno." Gazeta.ru, November 13. http://www.gazeta. $\mathrm{ru} / \mathrm{sport} / 2014 / 11 / 13 / \mathrm{a} \_6300101 . s h t m l$.

Gazeta.ru. 2014. “Otygratsya za Ukrainu." Gazeta.ru, July 11. http://www.gazeta.ru/ comments/2014/07/11_e_6110341.shtml.

Gazeta.ru. 2015a. "Mutko: Raskhody na podgotovku k ChM-2018 budut sokrashcheny na 10 protsentov." Gazeta.ru, January 29. http://www.gazeta.ru/sport/news/2015/01/29/n_6872165. shtml.

Gazeta.ru. 2015b. “Usmanov Vydelil RFS Den'gi Na Zarplatu Capello.” Gazeta.ru, February 5. http:// www.gazeta.ru/sport/news/2015/02/05/n_6896389.shtml.

Gazeta.ru. 2015c. "Peskov Zayavil, chto uroven zaniatii sportom Putina perekryvaet normy GTO.” Gazeta.ru, April 10. http://www.gazeta.ru/social/news/2015/04/10/n_7097061.shtml.

Golovin, B. 2015. "Futbolnyi Krym Ushol v odinochnoe plavanie." Gazeta.ru, January 23. http://www. gazeta.ru/sport/2015/01/23/a_6385477.shtml.

Greff, G. 2015. "Sberbank vyidet iz Krasnoi Polyany, kak tolko smozhet.” Slon, September 27. http:// slon.ru/fast/russia/german-gref-sberbank-vyydet-iz-krasnoy-polyany-kak-tolko-smozhet-996994. xhtml.

Hayward, P. 2015. “Ukraine Crisis: Fifa in Uncomfortable Position over 2018 Russia World Cup." The Telegraph, February 17. http://www.telegraph.co.uk/sport/football/world-cup/11418490/Ukrainecrisis-Fifa-in-uncomfortable-position-over-2018-Russia-World-Cup.html.

van Hilvoorde, I., A. Elling, and R. Stokvis. 2010. "How to Influence National Pride? The Olympic Medal Index as a Unifying Narrative." International Review for the Sociology of Sport 45 (1): 87-102.

KavkazUzel. 2014. "Kavkaz posle Olimpiady - prognozy Ekspertov." Kavkazskii Uzel, January 31. https://www.youtube.com/watch?v=HZME87me_hU\&feature=share.

Klimentyev, M. 2014. "Russia Faces Budget Deficit for 2018 World Cup." The Moscow Times, December 26. http://www.themoscowtimes.com/article/513915.html.

Kozhanova, D. 2013. "Investory Olimpiady vlastyam: predostavte lgoty, inache obyavim defolt." Slon, November 1. http://slon.ru/fast/russia/investory-olimpiady-vlastyam-predostavte-nalogovyelgoty-inache-obyavim-defolt-1013308.xhtml.

Krasil'nikov, S. 2013. "Razbitaya vitrina." Gazeta.ru, August 7. http://www.gazeta.ru/ comments/2013/08/07_e_5544897.shtml.

Kuus, M. 2002. "Sovereignty for Security? The Discourse of Sovereignty in Estonia." Political Geography 21 (3): 393-412. 
Makarov, I. 2015. “Sochi god spustya: 'Mozhno bylo sproektirovat stadion bez rekonstruktsii, no ne segodnya, a vosem let nazad"” Slon, February 6. http://slon.ru/insights/1212767/.

Makarov, I., and M. Sagomonian. 2015. "Postolympiiskoe oslozhnenie: sudba Sochi i ego \$60-milliardnykh proektov.” Slon, January 10. http://slon.ru/insights/1213512.

Makarychev, A., and S. Medvedev. 2015. "Biopolitics and Power in Putin's Russia." Problems of PostCommunism 62 (1): 45-54.

Makarychev, A., and A. Yatsyk. 2014. "The Four Pillars of Russia’s Power Narrative." The International Spectator 49 (4): 62-75.

Minca, C. 2007. "Agamben's Geographies of Modernity." Political Geography 26 (1): 78-97.

Mlssoccer. 2014. "FIFA Issues Statement Following Public Pressure to Strip Russia of 2018 World Cup." Mlssoccer Portal, July 25. http://www.mlssoccer.com/news/article/2014/07/25/fifa-issuesstatement-following-public-pressure-strip-russia-2018-world-cup.

Müller, M. 2014. Even Seizure: The World Cup 2018 and Russia's Illusive Quest for Modernization. Zürich. http://papers.ssrn.com/sol3/papers.cfm?abstract_id=2368219.

Muzhdabaev, A. 2014. "Samaya luchshaya Olimpiada." Ekho Moskvy, February 17. http://www.echo. msk.ru/blog/aiderm/1260346-echo/.

News.ru. 2015. "Stroitely Olympiiskikh obyektov v Sochi pozhalovalis Putinu na mnogomesyachnuyu zaderzhku zarplaty.” News.ru Agency, January 28. http://www.newsru.com/russia/28jan2015/ olimpobjectsochi.html.

Nikolaev, I. 2014. "Slishkom shchedraya dusha." Gazeta.ru, January 23. http://www.gazeta.ru/ comments/column/nikolaev/s62993/5860757.shtml.

Nili, S. (Shmulik). 2009. "The Rules of the Game - Nationalism, Globalisation and Football in Spain: Barça and Bilbao in a Comparative Perspective." Global Society 23 (3): 245-268.

Nye, J. 2014. "Putin's Rules of Attraction. Project Syndicat." ProjectSyndicate, December 12. http:// www.project-syndicate.org/commentary/putin-soft-power-declining-by-joseph-s-nye-2014-12.

Parker, N., and R. Adler-Nissen. 2012. "Picking and Choosing the 'Sovereign' Border: A Theory of Changing State Bordering Practices.” Geopolitics 17 (4): 773-796.

Persson, E. 2014. "Olympism and Empire: The Olympic Myth in the Contestation of the Caucasus." In The Sochi Predicament, edited by Bo Petersson and Karina Vamling, 72-94. Cambridge Scholars Publisher.

Pertsev, A. 2015. “Kladbishche geroev i nadezhd.” Slon, January 12. http://slon.ru/russia/kladbishche_ geroev_i_nadezhd-1203301.xhtml.

Reuters. 2013. "Soccer: Less Democracy Makes for an Easier World Cup - Valcke." Reuters, April 24. http://www.reuters.com/article/2013/04/24/us-soccer-fifa-idUSBRE93N18F20130424.

Rosenow, D. 2009. "Decentring Global Power: The Merits of a Foucauldian Approach to International Relations.” Global Society 23 (4): 497-517.

Rowe, D. 2003. "Sport and the Repudiation of the Global." International Review for the Sociology of Sport 38 (3): 281-294.

RSport. 2015. "Khokkeisty “Sochi” podadut zayavlenie v prokuraturu iz-za zaderzhki zarplaty." RSport Web-Site, May 13. http://rsport.ru/hockey/20150513/831423975.html.

RussianGovernment. 2015. "Ob izmeneniyakh v programme podgotovke k provedeniyu v Rossii v 2018 godu chempionata mira po futbolu." Russian Government Web Site, February 25. http:// government.ru/dep_news/16983/.

Sakharova, E. 2015. "Inostrantsev otfutbolili." Gazeta.ru, April 13. http://www.gazeta.ru/ realty/2015/04/13_a_6637373.shtml.

Saprykin, Y. 2015. “Olympiiskoe zvonkoe ekho: chto ostalos ot Igr v Sochi.” Slon, February 4. http:// slon.ru/insights/1211875.

SecureAvaaz. 2015. "Stop World 2018 Cup in Russia." SecureAvaaz.org Portal. https://secure.avaaz. org/de/petition/FIFA_Stoppt_die_FussballWM_in_Russland_2018/?fbss.

Selby, J. 2007. "Engaging Foucault: Discourse, Liberal Governance and the Limits of Foucauldian IR." International Relations 21 (3): 324-345.

Shlepchenko, V. 2013. "Proshchai kvartira, dacha i zemlya: zakonoproekt ob izyatii nedvizhimosti vnesion." Argumenty i Fakty, June 9. http://www.aif.ru/realty/countryside/44113. 
Singer, B. C. J., and L. Weir. 2006. "Politics and Sovereign Power: Considerations on Foucault." European Journal of Social Theory 9 (4): 443-465.

SkiRun. 2013. "Vasilii Parnyakov i Sergei Medvedev podveli itogi chempionata mira po liogkoi atletike v Moskve-2013 na radio Finam FM.” SkiRun Portal, August 22. http://skirun.ru/2013/08/22/ moscow-2013-itogi/.

Sukhotin, A. 2014. "Prezidenta Ostavlyaem Na Brustvere ...." Novaya Gazeta, August 11. http://www. novayagazeta.ru/politics/64784.html.

Super_ska_ya. 2014. “Kak popast na futbol v Kazani odetoi.” Live Journal Blog, August 25. http:// super-ska-ya.livejournal.com/27145.html.

Wendt, A. 1992. "Anarchy is What States Make of it: The Social Construction of Power Politics." International Organization 46 (2): 391-425.

Widder, N. 2004. "Foucault and Power Revisited." European Journal of Political Theory 3 (4): 411-432.

Wloch, R. 2012. "UEFA as a New Agent of Global Governance: A Case Study of Relations Between UEFA and the Polish Government Against the Background of the UEFA EURO 2012." Journal of Sport \& Social Issues 37 (3): 297-311.

YouTube. 2015. “Gimn Olimpiady v Sochi 2014 goda." YouTube.Portal. http://www.youtube.com/ watch?v=jyg91Tij5Ts.

Zaiviay, V. 2014. “Gollandskie konki boikotiruyut Rossiyu." Gazeta.ru, December 14. http://www. gazeta.ru/sport/2014/12/07/a_6332281.shtml.

Zayvyi, V. 2015. "Mutko - "khranitel klyuchei” ot Rossii." Gazeta.ru, August 3. http://www.gazeta. ru/sport/2015/07/31/a_7664245.shtml.

Zholobova, M. 2013. "Sochinskim investoram razreshili ne otdavat kredity do 2016 goda." Slon, December 16. http://slon.ru/fast/money/sochinskim-investoram-dali-poblazhki-1034959.xhtml.

Zizek, Z. 2006. "A leftist plea for 'Eurocentrism."' In The Universal Exception: Selected Writings, edited by R. Butler and S. Stephens, 184. London: Continuum. 